\title{
Determinants Of Long-Term Interest Rates In The United States
}

\author{
Charles Kweku Konadu-Adjei, Walden University, USA \\ Roger W. Mayer, Walden University, USA \\ Wen-Wen Chien, Berkeley College, USA
}

\begin{abstract}
The behavior of the long-term interest rates is a practical problem for private and public organizations. Organizations need to estimate interest rates for purposes of assigning value to long-term obligations such as defined benefit plans and long-term leases and making decisions related to long term capital purchases. The purpose of this study was to analyze the determinants of long-term interest rates in the United States, using 352 quarterly time series data points extending from 1999 to 2009. This study examines how a change in overnight interest rates, budget deficit, Gross Domestic Product (GDP), inflation, and net capital inflow impact on longterm interest rates, which is the 30-year U.S. Treasury constant securities rate. We find that the variables (overnight interest rates, expected inflation, budget deficit, foreign capital inflow, and $G D P)$ have statistically significant impact on long-term interest rates in the United States; all variables jointly explain changes in the long-term interest rates. The findings of this study can assist organization as they assign values to long-term obligations and assets.
\end{abstract}

Keywords: Long-Term Interest Rates; Gross Domestic Product; Overnight Interest Rates; Inflation; Budget Deficit

\section{INTRODUCTION}

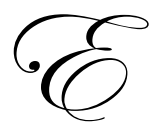

conomists and practitioners are interested in how to predict trends long-term interest rates (LTI) and interest rates trends (Wade, 2010). The ability to understand interest rate trends is of interest to policymakers, financial analysts, corporation leaders, and individuals who must make decisions based upon future interest rates (Adrian \& Shin, 2009; Blinder, 2010; Wade, 2010). LTI affect key interest-rate sensitive sectors of the U.S. economy, such as housing, auto, and investment; interest rates also affect corporate decisions related to pension and asset valuation (Saher \& Herbert, 2010).

Especially since the beginning of our current financial crisis starting in 2007, it is clear that interest rates impact the economic recovery. Unfortunately, the lack of accurate information related to future trends of LTI impairs the ability of organizations to accurately plan for the future (Adrian \& Shin, 2009). Policymakers, financial analysts, and organizations need to make specific decisions that are based, in part, on future interest rates trends.

Understanding determinants of LTI is critical for individuals who make decisions based upon LTI trends. The goal of this study is to increase our understanding of determinants of LTI in the United States by extending prior research by Saher and Herbert (2010) who examine determinants of LTI in Pakistan.

We examine the relationship between LTI (30-year U.S. Treasury constant securities rate) and overnight interest rate along with other key macroeconomic variables including GDP, inflation, net capital inflow, and budget deficit for the United States during a period from 1999-2009. We conduct our analysis in three steps: (a) a Johansen co-integration test (Johansen, 1988), (b) time series regression analysis with normalized co-integration coefficients, and finally (c) time series regression analysis with a vector error correction model to test our hypothesis. We find that overnight interest rates, budget deficit, net capital inflow, and inflation positively affect long-term interest rate whereas GDP negatively affects the long-term interest rate. In addition, our results indicate that overnight interest rates, inflation, net capital inflow, budget deficit, and GDP jointly explain, in part, the behavior of long-term interest LTI in the United States. 
This study contributes to the understanding of determinants of LTI. In addition, this study has a direct impact on accounting and finance. Accounting practitioners need to develop models that predict LTI for the financial statements presentation of long-term debt obligations and fair value measurements, which require time value of money calculations. The ability to predict LTI based upon current economic conditions is extremely valuable.

The next section introduces the background and hypothesis. Section 3 describes research methodology. Section 4 follows with data collection. Section 5 presents empirical results. The final section shows conclusion.

\section{BACKGROUND AND HYPOTHESIS}

The financial crisis experienced in the United States since 2007 was attributed to many factors, some of which include poor banking practices (Akram \& Christophersen, 2010; Volcker, 2008). One responsibility of leaders of the U.S. central bank is to use monetary policy to regulate and guide the U.S. economy. One of the primary tools used by officials of the United States Federal Reserve to regulate LTI and guide the economy is the overnight interest rate (Acharya \& Merrouche, 2009; Nautz \& Scheithauer, 2009). However, there is a dispute among economists about the effectiveness of central bank overnight interest rates in controlling the LTI and their impact on the economy.

When LTI increase, borrowing costs increase for home buyers, corporation leaders, and government; this has the effect of repressing economic growth (Irwin, 2009). As changes occur in interest rates, decisions for finance and accounting become more complex because of the interrelation between interest rates and accounting and finance decisions. Accounting and finance must make specific decisions related to asset and pension valuation; also decisions related to asset purchases are directly related to the analyst's understanding of future interest rates. Organizations also face challenges calculating year-end investment values when the valuation is dependent upon discount rate estimates. These estimates flow directly to the income statement and the balance sheet.

Results of prior research on interest rate determinants are mixed. Acharya and Merrouche (2009) suggest that overnight interest rates affect the longer-term money market rates. However, some economists, including Waterford (2005), argue that the use of overnight interest rate as a policy tool is outmoded and therefore, leaders of the central bank should discontinue its use as a policy instrument. In addition, Humpe and MacMillian (2006) argue that there is a negative relation between industry production and LTI and the consumer price index (CPI).

Researchers have indicated that overnight interest rate and the macroeconomic variables including GDP (Acharya \& Merrouche, 2009; Kashefi, 2008; Saher \& Herbert, 2010), budget deficit, expected inflation, and net capital inflow (Bandholz, Clostermann, \& Seitz, 2009; Saher \& Herbert, 2010) influence LTI. Because of the importance of predicting long-term interest rates and the mixed results of prior research on the determinates of LTI, we propose the following hypothesis:

$\mathrm{H}_{1}$ : There is a more frequently noticed statistically significant long-run relationship between quarterly overnight interest rates, expected inflation, budget deficit, foreign capital inflow, and GDP, and 30-year U.S. Treasury constant securities.

$\mathrm{H}_{0}$ (null): There is no frequently noticed statistically significant long-run relationship between quarterly overnight interest rates, expected inflation, budget deficit, foreign capital inflow, and GDP, and 30-year U.S. Treasury constant securities.

\section{RESEARCH METHODOLOGY}

\section{Research Design}

The study of the impact of overnight interest rates, along with other macroeconomic variables including expected inflation, budget deficit, net capital inflow, and GDP on LTI (30-year Treasury constant securities) in the United States from 1999 to 2009, were conducted using a time series design. We used 352 quarterly time series data 
points from 1999 to 2009 to measure the impact the independent variables have on the dependent variable (longterm interest rate). The approach for the study involved five independent variables (overnight interest rates, inflation rates, budget deficit, net capital inflow, and GDP) and one dependent variable (30-year Treasury constant securities). The empirical model was used to conduct the study.

\section{The Empirical Model}

This study uses the following model and examines the effect the overnight interest rates have on LTI. We follow the supply and demand models of the loanable fund theory estimated by Howe and Pigott (1992), Saher and Herbert (2010), and Onanuga and Shittu (2010) with some modifications to suit the objectives and data that were used. The general form of the long-run supply model is specified in Equation 1:

$\mathrm{SLF}=f(\mathrm{II}, \mathrm{LTI}, \mathrm{NKI}, \mathrm{OI})$

where

SLF $=$ Supply of Loanable Fund;

II = Expected Inflation;

LTI = Long-term Interest Rate;

NKI = Net Capital Inflow;

OI = Overnight Interest Rate.

In order to analyze the responsiveness of supply of loanable funds to each regressor, the specific form of the supply of loanable funds model is used, given the time series nature of the data available. Equation 2 is as follows:

$\mathrm{SLF}=\beta_{0}+\beta_{1} \mathrm{II}+\beta_{2} \mathrm{LTI}+\beta_{3} \mathrm{NKI}+\beta_{4} \mathrm{OI}+\varepsilon$

where

$\beta_{\mathrm{i}}=$ coefficient of the regressors and $i=0,1, \ldots, 4$;

SLF= Supply of Loanable Fund;

II = Expected Inflation;

LTI = Long-term Interest Rate;

NKI = Net Capital Inflow;

OI = Overnight Interest Rate;

$\varepsilon=$ Stochastic Disturbance term.

Further, the general form of the long-run demand for loanable fund model is specified given the time series properties of the data in Equation 3:

$\mathrm{DLF}=f(\mathrm{GDP}, \mathrm{BD}, \mathrm{II}, \mathrm{LTI})$

where

DLF $=$ Demand for Loanable Fund,

GDP = Income,

$\mathrm{BD}=$ Budget Deficit,

II = Expected Inflation,

LTI $=$ Long-term Interest Rate.

In addition, given that the sensitivity of demand for loanable fund to each regressor in Equation 3 is desired, the specific form is specified in Equation 4: 
$\mathrm{DLF}=\delta_{0}+\delta_{1} \mathrm{GDP}+\delta_{2} \mathrm{BD}+\delta_{3} \mathrm{II}+\delta_{4} \mathrm{LTI}+\varepsilon$

where

DLFt $=$ Demand for Loanable Fund;

$\delta_{i}=$ coefficient of regressors and $\mathrm{i}=1,2,3$.;

GDP = Income;

$\mathrm{BD}=$ Budget Deficit;

II = Expected Inflation;

LTI = Long-term Interest Rate;

$\varepsilon=$ Stochastic Disturbance Term.

At equilibrium, the supply of loanable funds is equal to the demand for loanable funds. The equation allows for the simultaneous solving of Equations 2 and 4. The solution to this problem provides the reduced form equation, which in its general form is specified in Equation 5:

$\mathrm{LTI}=f(\mathrm{II}, \mathrm{GDP}, \mathrm{BD}, \mathrm{NKI}, \mathrm{OI})$

All variables in the equation retained their original definition from the previous models. The specific form of Equation 5 that was estimated is given in Equation 6:

$\mathrm{LTI}=\Theta_{0}+\Theta_{1} \mathrm{II}+\Theta_{2} \mathrm{GDP}+\Theta_{3} \mathrm{BD}+\Theta_{4} \mathrm{NKI}+\Theta_{5} \mathrm{OI}+\varepsilon$

where

$\theta_{i}=$ coefficient of the reduced form regressors with $i=1,2,3,4$.

Equation 6 provides a model with expected inflation, GDP, budget deficit, net capital inflow, and overnight interest rate determining long-term interest rates.

\section{Analysis Technique}

We use Johansen's co-integration technique (Johansen, 1988) to establish meaning of long-run responses between the long-term interest rate and overnight interest rate. The Johansen's co-integration (Johansen, 1988) was adopted since the data to be used are time series data. A total of 352 quarterly data points were analyzed to establish the impact of overnight interest rate on long-term interest rates. The study involved five independent variables (overnight interest rate, budget deficit, expected inflation, foreign capital inflow, and GPD) and one dependent variable (30-year Treasury securities). Three different statistical tests were performed on each of the U.S. Treasury constant securities to ascertain the long-run relationship between the independent variables and the dependent variables.

\section{Overnight Interest Rate (OI)}

Nautz and Scheithauer (2009) argue that the overnight interest rate is the predominant tool used by the U.S. Federal Reserve officials to control the money market rates. The power for making interest rate decisions is split between the Board of Governors of the Federal Reserve, which is known as the Board, and the Federal Open Market Committee (FOMC). However, the decision on where to set overnight interest rates is the sole responsibility of FOMC members.

Changes (rise or fall) in the overnight interest rate affect bank leaders' decisions regarding borrowing and lending money. For example, a rise in the overnight interest rate discourages bank officials from borrowing, making the rate at which banks lend money high because demand for money will exceed supply for money. On the other hand, falling overnight interest rates motivate bank leaders to be likely to seek and invest in loans. 
Therefore, the overnight interest rate works like a regulatory instrument that controls the manner in which the U.S. economy works. From 1971 to 2010, the average interest rate in the United States was $6.45 \%$, hitting a record high of $20 \%$ in March of 1980 and a historical low of $0.25 \%$ in the last month of 2008 (Garrison, 2009). The overnight interest rate impacts the longer-term money market rate, including the U.S. Treasury constant securities (Acharya \& Merrouche, 2009), resulting in a shift in the overnight interest rate and a corresponding shift in the Treasury constant securities.

Acharya and Merrouche (2009) argue that changes in overnight interest rate impact long-term money market rates, which in turn affect the lending and borrowing rates faced by members of firms and households, thus impacting their investment and consumption decisions.

\section{Budget Deficit (BD)}

Officials of the federal government are principal borrowers of banking sector funds and, because of their position; therefore the need from the government to borrow more money to finance its high budget deficit may have significant repercussions on long-term interest rates (Saher \& Herbert, 2010). The federal deficits of the 1980s and the early parts of the 1990s resulted in contemplation as to whether higher interest rates would follow (Wang \& Rettenmaier, 2008). The current deficits have renewed interest in the connection to future higher interest rates. In addition, Quayes and Jamal (2007) found that rising budget deficits result in higher long-term interest rates for corporate bonds in the United States.

Barnes (2008) explores the relationship between budget deficits and LTI for ten European countries and finds LTI is positively impacted by budget deficits. Similarly, Saher and Herbert (2010) find that budget deficit has positive impacts on long-term interest rate in Pakistan. In this study, budget deficit was computed as the difference between government revenue and expenditure and was measured in millions of dollars

\section{Net Capital Flow (NKI)}

Long-term interest rates have been impacted by capital inflow into U.S. securities markets, (Krishnamurthy \& Vissing-Jorgensen, 2010, 2011). Picker (2010) argues that the conundrum surrounding the trend or the pattern of long-term interest rates can be explained by the impact of capital inflow, which has paramount monetary and numerical impact on long-term interest rates in the United States. The global environment has an impact on interest rates in the United States (Sawyer \& Minadeo. 2008). Picker explained that foreign purchases of U.S. government bonds have led to low levels of U.S. long-term interest rates that U.S. officials are experiencing. De Loubens, Idier, and Jardet (2007) study the factors affecting the U.S. and European long-term interest rates between 1986 and 2005 and find that the bursting of the Internet bubble, purchases by foreign agents, both public and private, and the increase in global liquidity exerted downward pressure on U.S. long-term interest rates. In addition, Krishnamurthy and Vissing-Jorgensen $(2010,2011)$ suggests that the U.S. central bank's purchases of longer-term securities impacts the trend of long-term interest rates.

Prior study by Saher and Herbert (2010) shows net capital inflows have negative impact on the long-term interest rates in Pakistan. The negative impact of net inflow on long-term interest rates is an indication that massive capital inflow into a nation results in excess amount of money circulating in the system, which decreases the actual rate of loaning out money and motivates investment. Cebula (1997) uses the data ranging from 1973 to 1993 on France's economy and indicates that, in an industrialized country, capital inflows reduce long-term interest rates. Warnock and Warnock (2008) find foreign capital inflows have huge economically and statistically significant effects on long-term interest rate. Ioana and Diana (2010) presented a connection between massive capital inflows, debt crises, inflation, and long-term interest rates issues. Net capital inflow (NKI) computed as the total of foreign direct investments and net private transfers as used in Ioana and Diana (2010) study. NKI is also measured in billion dollars in this study.

\section{Expected Inflation (II)}

Inflation is one of the main reasons why there have been ups and downs in interest rates (Thorbecke \& Zhang, 2009). Wu (2005) argues that long-term interest rates are associated with long-run inflation expectations. 
Ireland (1997) indicates that policymakers explained the rapid increases in long-term bond rates as the outcome of increasing inflationary expectations, depicting a loss of credibility of the Federal Reserve fight against inflation.

Inflation is measured by the Consumer Price Index (CPI) and the Producer Price Index (PPI). Expected inflation (II) is computed in this study as the percentage change in the CPI.

\section{GDP}

In this study, income was proxied by GDP in billions of dollars. Because GDP is the most essential economic barometer, it represents a wide range of economic activity assessment and indicates the pathway of overall aggregate economic activity. In view of this, an increase in nominal GDP results in an increase in spending. Similarly, this means demand for money also must increase to meet spending needs. Should the money supply not increase to meet the demand for money, the result will be high interest rates. Researchers indicated that the continuous decrease in U.S. GDP growth has affected the long-term interest rates (Gale \& Orszag, 2004). Saher and Herbert (2010) find that GDP is positively associated with long-term interest rate.

\section{DATA COLLECTION}

This study uses exclusive quarterly time series data covering the period of January 1999 to December 2009. The time frame was of great interest to economists, financial analysts, and policymakers because the era had experienced both economic and regime changes and disruptions. In addition, quarterly data were selected over monthly or daily data because most of the economic variables to be tested were published either quarterly or annually. The analysis of the data includes one dependent variable (LTI) and five independent variables.

We collected a total of 352 quarterly data points to analyze how the LTI respond to the overnight interest rate along with budget deficit, expected inflation, foreign capital inflow, and GPD. Data on GDP and net capital inflows were obtained from the Bureau of Economic Analysis of the U.S. Department of Commerce. Information pertaining to the budget deficit was gathered from the website of the Office of Management and Budget. The Consumer Price Index was obtained from the Federal Reserve and Bureau of Labor Statistics within the U.S. Department of Labor. The data for the LTI and overnight interest rate were collected from the website of the Federal Reserve.

\section{EMPIRICAL RESULTS}

\section{Unit Root Test}

We follow Gervais and Khraief (2007) to apply the Augmented Dickey-Fuller unit root tests on the levels of the variables of interest to ascertain whether the variables were stationary. Table 1 reports the results of the stationarity test. All the variables are nonstationary at the 5\% significant level. To make them stationary, the first differences were taken. In addition, Table 2 shows that the results of the unit root test on the first differences of all the variables are stationary at the $5 \%$ significant level. The results show that all the variables were integrated at order zero.

Table 1: Augmented Dickey-Fuller Unit Root Tests in Levels

\begin{tabular}{|l|c|c|c|c|}
\hline \multicolumn{1}{|c|}{ Variable } & $\begin{array}{c}\boldsymbol{t} \text {-ADF } \\
\text { Constant only) }\end{array}$ & $\begin{array}{c}\text { Critical Value } \\
\mathbf{5 \%}\end{array}$ & $\begin{array}{c}\text { MacKinnon } \\
\boldsymbol{p} \text {-value }\end{array}$ & $\begin{array}{c}\text { Order of } \\
\text { Integration }\end{array}$ \\
\hline LTI & -1.42 & -2.95 & .57 & Not at 0 \\
\hline OI & -0.44 & -2.95 & .90 & Not at 0 \\
\hline INF & -2.56 & -2.95 & .10 & Not at 0 \\
\hline NKI & -3.12 & -2.95 & .07 & Not at 0 \\
\hline BD & -3.13 & -2.95 & .06 & Not at 0 \\
\hline GDP & -1.19 & -2.95 & .68 & Not at 0 \\
\hline
\end{tabular}


Table 2: Augmented Dickey-Fuller Unit Root Test in Difference

\begin{tabular}{|l|c|c|c|c|}
\hline \multicolumn{1}{|c|}{ Variable } & $\begin{array}{c}\boldsymbol{t} \text {-ADF } \\
\text { (Constant only) }\end{array}$ & $\begin{array}{c}\text { Critical Value } \\
\mathbf{5 \%}\end{array}$ & $\begin{array}{c}\text { MacKinnon } \\
\boldsymbol{p} \text {-value }\end{array}$ & $\begin{array}{c}\text { Number } \\
\text { of Lags }\end{array}$ \\
\hline LTI & -5.82 & -2.95 & $<.001$ & 1 \\
\hline OI & -7.97 & -2.96 & $<.001$ & 1 \\
\hline INF & -4.76 & -2.95 & $<.001$ & 1 \\
\hline NKI & -8.92 & -2.95 & $<.001$ & 1 \\
\hline BD & -9.80 & -2.95 & $<.001$ & 1 \\
\hline GDP & -3.22 & -2.95 & .02 & 1 \\
\hline
\end{tabular}

\section{Test of Co-integration for the LTI Model}

We test null hypothesis 1 to determine whether there is no frequently-noticed statistically significant longrun relationship between quarterly overnight interest rates, expected inflation, budget deficit, net capital inflow, and GDP, and LTI. We also use a time series design utilizing regression to test the hypothesis. Table 3 reports the result of the Johansen co-integration test. In conducting the co-integration test, the no deterministic trend assumption was used because of the characteristics of the line plots (see Figure 1) of the LTI.

Table 3: Results of the Johansen Co-integration Tests for LTI Model

\begin{tabular}{|c|c|c|c|}
\hline Eigenvalue & $\begin{array}{c}\text { Trace } \\
\text { statistic }\end{array}$ & $\begin{array}{c}\text { Critical value } \\
\mathbf{5 \%}\end{array}$ & $\begin{array}{c}\text { Hypothesized } \\
\text { no. of CE(s) }\end{array}$ \\
\hline & & & None \\
\hline 0.72 & 144.92 & 94.15 & At most 1 \\
\hline 0.57 & 91.64 & 68.52 & At most 2 \\
\hline 0.48 & 56.33 & 47.21 & At most 3 \\
\hline 0.39 & $28.94 *$ & 29.68 & At most 4 \\
\hline 0.16 & 8.32 & 15.41 & At most 5 \\
\hline 0.02 & 0.86 & 3.76 & At Most 5 \\
\hline
\end{tabular}

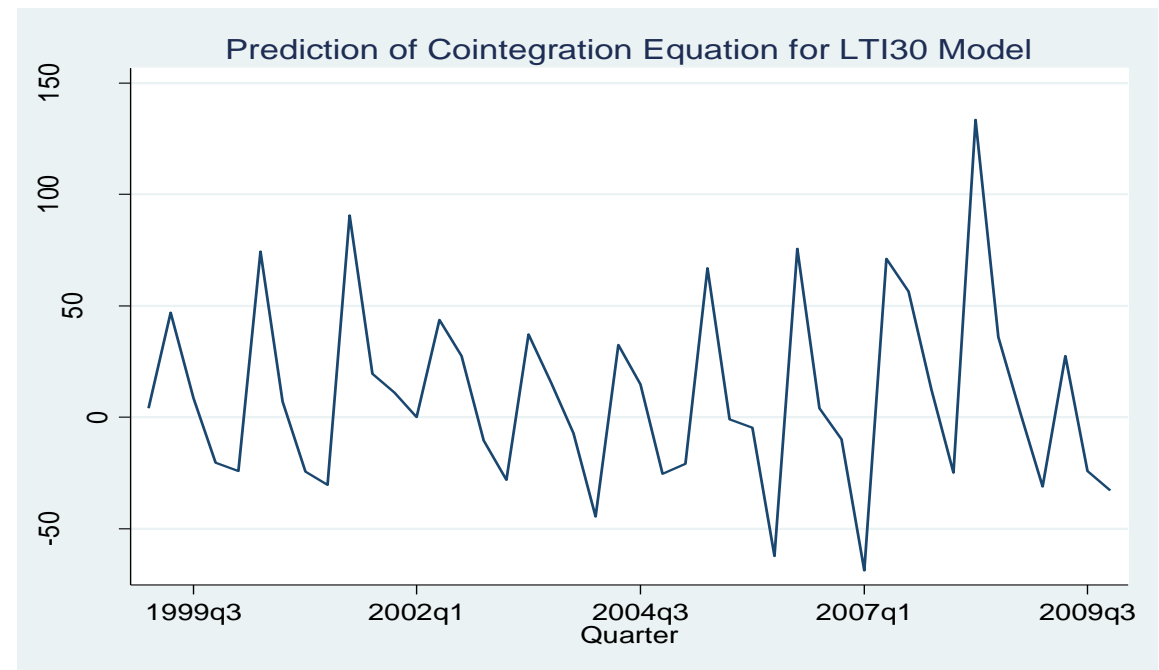

Figure 1: Line graph for cointegration equation of the LTI Model from 1999 to 2009

\section{Normalized co-integration coefficient results LTI model}

In conducting the co-integration test, the no deterministic trend assumption is used because it is consistent with the Augmented Dickey-Fuller (ADF) test (Gervais \& Khraief, 2007). Table 4 reports the normalized co- 
integration coefficient results from the analysis. The reported normalized equation which expressed the long-run relationship between the LTI and all the independent variables is written as follows:

$\mathrm{LTI}=130.3579+6.5528 \mathrm{OI}+5.3243 \mathrm{INF}+0.1230 \mathrm{NKI}+1.3072 \mathrm{BD}-19.6586 \mathrm{GDP}$

Hence, there is a long-run relationship between the LTI and the independent variables. The regression shows that overnight interest rate has positive and significant effect on the LTI. This relationship supports Blinder (2009) and Krishnamurthy and Vissing-Jorgensen (2010) arguments. It is therefore not surprising that the coefficient of the variable is statistically significant at 5\% $(p<.05)$. The result also shows that a 1 percentage point increase in the overnight interest rates increases the LTI by 6.55 basis points.

In addition, inflation has the expected positive sign and is statistically significant at $1 \%(p<.05)$. This finding conforms to Rahman (2009) in that when inflation increases, it will put an upward pressure on the LTI and hence lead to an increase in the interest rate. Regression results indicate that a 1 percentage point increase in inflation will lead to 5.32 basis point increase in the LTI.

Further, the net capital inflow which represents the total of foreign direct investments and net private transfers is positive and statistically significant at $1 \%(p<.001)$. Thus, a $1 \%$ increase in the net capital inflow will cause the LTI to increase by 0.12 percentage point. The coefficient for budget deficit was negative and statistically significant $1 \%(p<.001)$. On average, a 1 percent increase in the budget deficit will result in an increase in the LTI by1.30 basis points. This result is consistent with (Baer, 2003; Labonte, 2005) argument. Finally, GDP indicated a statistically significant negative relationship with the LTI $(p<.001)$. The result indicated that an increase in GDP by 1 percent will lead to a decrease in the long term interest rate by 19.65 basis points. The results suggest the presence of no unique co-integrating relationships.

Table 4: Normalized Co-integration Coefficients for LTI Model

\begin{tabular}{|l|c|c|c|c|}
\hline \multicolumn{1}{|c|}{ Variable } & B & SE & z-Stat & p-value \\
\hline LTI & 1.00 & & & .005 \\
\hline OI & -6.55 & 2.34 & -2.79 & .040 \\
\hline INF & -5.32 & 3.27 & -1.63 & $<.001$ \\
\hline NKI & -0.12 & 0.03 & -4.39 & $<.001$ \\
\hline BD & -1.31 & 0.16 & -8.35 & $<.001$ \\
\hline GDP & 19.66 & 2.62 & 7.49 & \\
\hline Constant & -130.36 & & & \\
\hline
\end{tabular}

\section{Error correction term for the LTI model}

The vector error correction model was constructed in order to appreciate the short-run dynamics of the effects of all the independent variables on the LTI, having established that a long-run relationship exists between the variables. Table 5 shows that the error correction term, which signifies the speed at which adjustment of the LTI to its long-run equilibrium level occurs, is negative and statistically significant at the $1 \%$ level. The negative coefficient of the error correction term confirms the existence of long-run equilibrium relationship of the model. An error correction term of $0.5 \%$ implies that the feedback into the short-run dynamic process from the previous period is $0.5 \%$. This means that the adjustment from the short-run to long-run equilibrium is about $0.5 \%$. In addition, Table 5 shows the evidence that justifies the use of the error correction model. This combination of findings provided support to reject Null Hypothesis 1.

The results of the time series regression analysis with a vector error correction model indicate that there is a significant a long-run relationship between budget deficit $(B=-0.003, p=.02)$ and LTI, $p<.001$ (see Table 5). The results further indicate that approximately $90 \%$ of the variance is explained by $\mathrm{R}^{2}=.65$ and $F=62.66$ (see Table 5). Table 5 shows results with good explanatory power of the model as indicated by the $R^{2}$ and $F$-statistic. 
Table 5: Vector Error Correction Model Results for LTI Model

\begin{tabular}{|l|c|c|c|}
\hline \multicolumn{1}{|c|}{ Variable } & $\boldsymbol{B}$ & $\boldsymbol{S} \boldsymbol{z}$ & $\boldsymbol{z}$-Stat \\
\hline D.LTI10(-1) & 0.180 & 0.1600 & -1.16 \\
\hline D.OI(-1) & -0.080 & 0.1000 & -1.23 \\
\hline D.INF(-1) & -0.080 & 0.0600 & -0.15 \\
\hline D.NKI(-1) & -0.0001 & 0.0004 & -2.40 \\
\hline D.BD(-1) & -0.003 & 0.0010 & 0.04 \\
\hline D.GDP(-1) & 0.030 & 0.6500 & -2.92 \\
\hline Error Correction Term & -0.005 & 0.002 & 0.15 \\
\hline Constant & 0.020 & 0.1000 & 62.66 \\
\hline$R^{2}$ & .65 & $F$ & \\
\hline
\end{tabular}

The Akaike's information criterion (AIC) indicates that a lag length of one was optimum as well as the other information criteria. The predicted co-integration equation for LTI Model indicated that there are large shocks in the 30-year U.S. Treasury constant securities rates during the years under review. As indicated in Figure 1, the third quarter of year 2006 and the first quarter of the year 2007 experienced the most shock. In addition, Table 6 shows that the moduli of the remaining eigenvalues are strictly less than one.

Table 6: Eigenvalue Stability Condition for LTI Model

\begin{tabular}{|c|c|c|}
\hline Eigenvalue & & Modulus \\
\hline 1 & & 1 \\
\hline 1 & & 1 \\
\hline 1 & & 1 \\
\hline 1 & & 1 \\
\hline 1 & & 1 \\
\hline-0.1574944 & $+.7087155 \mathrm{i}$ & 0.726004 \\
\hline-0.1574944 & - .7087155i & 0.726004 \\
\hline 0.6993272 & & 0.699327 \\
\hline-0.6369549 & & 0.636955 \\
\hline 0.4010322 & $+.2129462 \mathrm{i}$ & 0.454063 \\
\hline 0.4010322 & $-.2129462 \mathrm{i}$ & 0.454063 \\
\hline-0.2275654 & & 0.227565 \\
\hline
\end{tabular}

\section{CONCLUSION}

The objective of this research is to measure how each determinant (Overnight interest rate, budget deficit, expected inflation, GDP, and foreign capital inflow) affects LTI in the United States. The U.S. Federal Reserve has many monetary policy tools to influence the long-term interest rates; however, the tool that has received the most attention in the mainstream literature is the overnight interest rate (Adrian \& Shin, 2009). Our study suggests that besides overnight interest rates other variables impact the direction of LTI including GDP, inflation, budget deficit, and net capital inflow.

Economic theory offers differing views on the overnight interest rates-long-term interest rates relationship (Waterford, 2005; Ranaldo \& Reynard, 2008). We conduct this study to ascertain the relationship empirically. The approach is to review professional and academic literature and to adopt the demand for loanable funds and supply for loanable funds as the empirical model to determine the impact of (a) overnight interest rates, (b) GDP, (c) budget deficit, (d) inflation, and (e) net capital on long-term interest rates. The statistical tool employed to examine 352 quarterly time series data in this study is Johansen's co-integration model (Johansen, 1988). We use the data retrieved from government databases such as the Bureau of Economic Analysis of the U.S. Department of Commerce, Office of Management and Budget, and Bureau of Labor Statistics within the U.S. Department of Labor and Federal Reserve. 
We find statistically significant relationship between long-term interest rates and the independent variables (overnight interest rates, inflation, budget deficit, net capital inflow, and GDP). The results indicate that the overnight interest rates have statistically significant impact on the LTI in the United States. In addition, our results show that inflation, net capital inflow, budget deficit, and GDP jointly explain the behavior of long-term interest rate in the United States. Overnight interest rates, budget deficit, net capital inflow, and inflation positively affect longterm interest rate whereas GDP negatively affects the long-term interest rate.

This study supports prior research on the impact of quarterly (a) overnight interest rates, (b) expected inflation, (c) budget deficit, (d) net capital inflow, and (d) GDP on long-term interest rates. Our results suggest that a change in any of the independent variables will affect the long-term interest rates in the United States. However, this relationship may be affected by several other factors. Therefore, this study calls for further examination on other factors that may possibly affect how the long-term interest rates response to overnight interest rates.

\section{AUTHOR INFORMATION}

Dr. Charles Kweku Konadu-Adjei Doctoral Student, Walden University. E-mail: charles.konaduadjei@waldenu.edu

Dr. Roger W. Mayer, Instructor, Walden University. E-mail: roger.mayer@waldenu.edu. Corresponding author.

Dr. Wen-Wen Chien, Instructor of Accounting, Berkeley College. E-mail: chienerica@yahoo.com. Corresponding author.

\section{REFERENCES}

1. Acharya, V. V., \& Merrouche, O. (2009). Precautionary Hoarding of Liquidity of Inter-Bank Markets: Evidence From The Sub-Prime Crisis. Retrieved From http://pages.stern.nyu.edu/ sternfin/vacharya/public html/acharya merrouche.pdf

2. Adrian, T., \& Shin, H. S. (2009). Price and Quantities In The Monetary Policy Transmission Mechanism. Retrieved From http://www.ny.frb.org/research/staff_reports/sr396.pdf

3. Akram, F., \& Christophersen, C. (2010). Interbank Overnight Interest Rates Gains From Systemic Importance. Retrieved From http://www.norgesbank.no/upload/publikasjoner/staff\%20memo/2011/staff_memo_0111.pdf

4. Baer, E. (2003). Budget Deficits of Interest Rates: To Crowd Or Not To Crowd? Retrieved From http://userwww.service.emory.edu/ skrause/e711/partv/baer-2003.pdf

5. Bandholz, H., Clostermann, J., \& Seitz, F. (2009). Explaining The US Bond Yield Conundrum. Applied Financial Economics, 19, 539-550.

6. Barnes, B. (2008). A Co-Integrating Approach to Budget Deficits of Long-Term Interest Rates. Applied Economics, 40, 127-133.

7. Blinder, A. (2010). How Central Should The Central Bank Be? Journal of Economic Literature, 48(1), 123-133.

8. Cebula, R. J. (1997). The Impact of Net International Capital Inflows on Nominal Long-Term Interest Rates In France. Atlantic Economic Journal, 25, 179-190.

9. De Loubens, A., Idier, J., \& Jardet, C. (2007). Determinants of Long-Term Interest Rates In The United States of The Euro Area: A Multivariate Approach. Retrieved From http://ideas.repec.org/p/bfr/banfra/170.html

10. Gale, W. G., \& Orszag, P. R. (2004). The Budget Outlook: Projections of Implications. The Economists' Voice, 1(2), Article 6. Retrieved From http://www.brookings.edu/articles/2004/1025federalbudget_gale.aspx

11. Garrison, R. (2009). Interest-Rate Targeting During The Great Moderation: A Reappraisal. Cato Journal, 29(1), 187-200.

12. Gervais, J. P., \& Khraief, N. (2007). Is Exchange Rate Pass-Through In Pork Meat Export Prices Constrained By The Supply of Live Hogs? American Journal of Agricultural Economics, 89, 1058-1072. 
13. Gul, E., \& Acikalin, S. (2008). An Examination of The Fisher Hypothesis: The Case of Turkey. Applied Economics, 40(24), 3227-3231.

14. Howe, H., \& Pigott, C. (1992, Winter). Determinants of Long-Term Interest Rates: An Empirical Study Several Industrial Countries. FRBNY Quarterly Review, 12-28.

15. Humpe, A., \& Macmillian, P. (2006). Can Macroeconomic Variables Explain Long Term Stock Market Movements? A Comparison of the U.S. and Japan. Retrieved From http://www.standrews.ac.uk/crieff/papers/dp0511.pdf

16. Hsing Y. (2007). Effects of the Intended and Unintended Federal Funds Rates on the Treasury Yield Curve During The Greenspan Era. Applied Financial Economics Letters, 3(3), 155-159.

17. Ireland, P. N. (1997). Long-Term Interest Rates of Inflation: A Fisherian Approach. Economic Quarterly Federal Reserve Bank of Richmond, 82(1), 21-35.

18. Irwin, N. (2009). Spike In Interest Rates Could Choke Recovery. Retrieved From http://www.washingtonpost.com/wp-dyn/content/article/2009/06/11/ar2009061104297.html

19. Ioana, C. S., \& Diana, S. P. C. (2010). Causes of Consequences of Massive Capital Flows. Retrieved From http://anale.steconomiceuoradea.ro/volume/2010/n1/065.pdf

20. Johansen, S. (1988). Statistical Analysis of Co-Integration Sectors. Journal of Economic Dynamics of Control, 12(3), 231-234.

21. Kashefi, J. (2008). The Effect of Changes in The Federal Funds Rate on Value of Growth Stock Prices: A Threshold Garch Approach. International Research Journal of Finance of Economics, 17, 1-15.

22. Krishnamurthy, A., \& Vissing-Jorgensen, A. (2010). The Effects of Quantitative Easing on Long-Term Interest Rates. Retrieved From http://www.fma.org/napa/papers/treasuries.pdf

23. Krishnamurthy, A., \& Vissing-Jorgensen, A. (2011). The Effects of Quantitative Easing on Interest Rates: Channels of Implications For Policy. Retrieved From http://www.kellogg.northwestern.edu/faculty/vissing/htm/qe_paper.pdf

24. Labonte, M. (2005). Do Budget Deficits Push Up Interest Rates of Is This The Relevant Question? Retrieved From http://www.policyarchive.org/handle/10207/ bitstreams/1634.pdf

25. Nautz, D., \& Scheithauer, J. (2009). Monetary Policy Implementation of Overnight Rate Persistence. Journal of Banking \& Finance, 33(7), 1274-1278.

26. Onanuga, A. T., \& Shittu, A. M. (2010). Determinants of Interest Rate in Nigeria: An Error Correction Model. Journal of Economics of International Finance, 2(12), 261-271.

27. Picker, L. (2010). International Capital Flows Alter U.S. Interest Rates. Retrieved From http://www.nber.org/digest/nov06/w12560.html

28. Quayes, S., \& Jamal, A. M. M. (2007). Budget Deficits of Interest Rates: The U.S. Evidence Since 1946. The Singapore Economic Review, 52(2), 191-200.

29. Rahman, S. (2009). The Effects of Inflation Uncertainty: Some International Evidence. Journal of Economic Studies, 36(5), 541-550.

30. Ranaldo, A., \& Reynard, S. (2008). Monetary Policy Effects on Long-Term Rates of Stock Prices. Retrieved From http://www.ranaldo.net/pdf/work_in_progress/monpolfinmar1.pdf

31. Saher, N., \& Herbert, M. (2010). Response of Long-Term Interest Rate to Fiscal Imbalance: Evidence From Pakistan. SBP Research Bulletin, 6(1), 43-48.

32. Thorbecke, W., \& Zhang, H. (2009). Monetary Policy Surprises of Interest Rates: Choosing Between the Inflation-Revelation of Excess Sensitivity Hypotheses. Southern Economic Journal, 75(4), 1114-1122.

33. Volcker, P. (2008). Rethinking the Bright New World of Global Finance. International Finance, 11(1), 101-107.

34. Wade, R. (2010). From Global Imbalances to Global Reorganizations. Cambridge Journal of Economics, 33(1), 539-562.

35. Wang, Z., \& Rettenmaier, A. J. (2008). Deficits, Explicit Debt, Implicit Debt, of Interest Rates: Some Empirical Evidence. Southern Economic Journal, 75(1), 208-222.

36. Waterford, M. (2005). Comment on Using A Long-Term Interest Rate As The Monetary Policy Instrument. Retrieved From http://www.columbia.edu/ mw2230/crcomment-longterminstrument.pdf

37. Warnock, F. E., \& Warnock, V. C. (2008). International Capital Flows of U.S. Interest Rates. Journal of Monetary Economics, 52(5), 881-887. 


\section{NOTES}

